UDC 616.98:579.834.114-036-07-08-06:616.833.17

https://doi.org/10.26641/2307-0404.2020.4.221779

\title{
I.M. Poiasnyk \\ FACIAL PALSY AS A MANIFESTATION OF EARLY NEUROBORRELIOSIS (clinical case)
}

Ivano-Frankivsk National Medical University

Department of Neurology and Neurosurgery

Halytska str., 2, Ivano-Frankivsk, 76018, Ukraine

e-mail: sof.3425@gmail.com

CNE "Ivano-Frankivsk Regional Clinical Hospital"

Fedkovycha str., 91, Ivano-Frankivsk, 76000, Ukraine

Івано-Франківський національний медичний університет

кафедра неврології та нейрохірургії

(зав. - д. мед. н., проф. В.А. Гриб)

вул. Галицька, 2, Івано-Франківськ, 76018, Украӥна

КНП «Івано-Франківська обласна клінічна лікарня»

вул. Федьковича, 91, Івано-Франківськ, 76000, Украӥна

e-mail:info@okl.if.ua

Цитування: Медичні перспективи. 2020. Т. 25, № 4. С. 214-220
Cited: Medicni perspektivi. 2020;25(4):214-220

Key words: peripheral facial palsy, Lyme disease, neuroborreliosis, diagnosis, treatment

Ключові слова: нейропатія лицевого нерва, хвороба Лайма, нейробореліоз, діагностика, лікування

Ключевые слова: нейропатия лицевого нерва, болезнь Лайма, нейроборелиоз, диагностика, лечение

\begin{abstract}
Facial palsy as a manifestation of early neuroborreliosis (clinical case). Poiasnyk I.M. Lyme borreliosis is a tick-borne transmitted infectious disease caused by the spirochete Borrelia burgdorferi sensu lato and spread by the bite of ticks of the genus Ixodes. Lyme neuroborreliosis is a clinical manifestation of Lyme borreliosis, which affects the central nervous system and peripheral nervous system in up to $15 \%$ of the affected patients. Nerve structures are affected by spirochetes both in acute and late phase of the disease. The clinical course of neuroborreliosis is highly variable. Although at least $80 \%$ of European patients present with facial nerve palsy and radiculitis, symptoms of neuroborreliosis may be quite unspecific or even mimic other neurological diseases. Idiopathic peripheral facial palsy has long been considered as the most common cause of prosopoparesis, but modern diagnosis significantly narrow the range of cases of unknown genesis. Neuroborreliosis is difficult to diagnose, especially when prosopoparesis is the only clinical manifestation, so practitioners should be mindful of possible etiology to avoid misdiagnosis. The article presents a clinical case of early neuroborreliosis in a woman of 57 years who manifested with peripheral facial palsy. The author describes in detail the course of the disease (the appearance of new symptoms on the background of standard medical therapy (poor response), the presence of additional criteria (erythema migrans, lymphocytoma (rarely), arthralgia), diagnosis (specific immunological examination of blood to Borrelia burgdorferi sensu lato). Antibiotic therapy made it possible to achieve complete recovery of facial nerve function and avoid future complications.
\end{abstract}

Реферат. Нейропатия лицевого нерва как манифестация раннего нейроборелиоза (клинический случай). Пояснык И.М. Лайм-боррелиоз - это передаваемое клещами инфекиионное заболевание, вызываемое спирохетой Borrelia burgdorferi sensu lato и распространяемое укусом клещей рода Iходеs. Нейроборрелиоз является клиническим проявлением болезни Лайма, которая поражает центральную и периферическую нервную систему у 15\% пациентов. Нервная система поражается как в острой, так и в поздней фазе заболевания. Клиническое течение нейроборрелиоза сильно варьирует. Хотя по меньшей мере $80 \%$ европейских паџиентов страдают параличом лицевого нерва и радикулитом, симптомы нейроборрелиоза могут быть совериенно неспецифичными или даже имитировать другие неврологические заболевания. Идиопатическая невропатия лицевого нерва длительное время рассматривалась как наиболее распространенная причина прозопопареза, однако современная диагностика значительно сужает круг случаев неизвестного происхождения. Нейроборелиоз трудно диагностировать, особенно когда прозопопарез является единственным клиническим проявлением, поэтому практикуюшие врачи должны помнить о возможной этиологии, чтобы избежать ошибки. В статье приведен клинический случай раннего нейроборелиоза у женщины 57 лет, который манифестировал с нейропатии лицевого нерва. Автор подробно описывает ход заболевания (появление новых симптомов на фоне стандартной медикаментозной терапии (плохой ответ), наличие вспомогательных критериев (мигрирующая эритема, лимфоцитома (редко 
случается), артралгии), диагностику (специфическое иммунологическое исследование крови к Borrelia burgdorferi sensu lato), которая помогла в назначении правильного лечения пациентки. Антибиотикотерапия позволила достичь полного восстановления функции лицевого нерва и избежать будущиих осложнений.

Lyme disease (LD) is a multisystem infectious transmissible natural-focal disease caused by spirochetes of the Borrelia burgdorferi sensulato complex and transmitted by Ixodes mites, being developed when bacteria spread from a bite site to various organs and tissues. Neuroborreliosis is a neurological manifestation of Lyme disease that can affect both the peripheral and central nervous systems, including neurological conditions such as cranial nerve damage (including facial) and aseptic meningitis. Neuroborreliosis often mimics the clinic of other neurological pathologies $(16.7 \%)$, so untimely diagnosis and treatment leads to chronicity (3.5-10.6\% of cases), long-term invalidism, disability and sometimes death [9].

In Ukraine, the first cases of people with LD were diagnosed in 1994. Official registration of the disease has been conducted since 2000 . The number of cases of this pathology is constantly growing every year, which is associated with improved diagnostics. The incidence of LD in Ukraine in 2000-2010 increased by 29 times. In 2000-2004, 562 cases of LD were detected, and in 2012-2014 it was registered in 5,264 people in Ukraine [4]. For 7 months of 2018, 2403 cases of LD were registered, as well as one case of tick-borne viral encephalitis [1]. The western region of Ukraine is recognized as an endemic center of LD because its location in the forest-steppe zone and in the zone of mixed forests with fertile soils and sufficient moisture, optimal temperature creates favorable conditions for the circulation of pathogens of Ixodes tick-borne borreliosis [3].

Seasonal activity of I. ricinus in Ukraine has two pronounced peaks - in April-May and August-September. Every year there is an increase in the duration of the season of mite activity, which, in our opinion, is facilitated by climatic conditions, namely the onset of early spring and long warm autumn. Thus, the incidence of LD is registered throughout the year with a maximum that persists with the seasonal activity of ticks [3].

Different strains cause different forms of the disease. The European version of LD is especially associated with neurological manifestations, including facial nerve palsy. Because the symptoms of LD are nonspecific, it can be misdiagnosed as facial nerve palsy, making it impossible to properly treat it with medications. Experts say that if the bitten lives in an endemic area, you need to be especially prepared to diagnose the disease, because it mani- fests itself in various forms. If the disease is diagnosed at an early stage, $>95 \%$ of patients with LD can expect a complete cure $[10,17]$.

In a significant proportion of patients, the onset of symptoms of LD is preceded by migrating erythema (ME) [7, 11]. Features of a typical ME:

- the period of time between a tick bite and the onset of erythema is usually from 3 days to several weeks;

- increase in the centrifugal spread of erythema;

- limited, erythema having a diameter of at least $5 \mathrm{~cm}$;

- visible bite site in the center of the erythema.

At an early stage, the appearance of benign lymphocytoma (cutaneous lymphoid hyperplasia, (rare)) at the site of the bite or together with ME.

The main signs of benign lymphocytoma:

- mostly single, more often in children;

- localized, mainly on the earlobes, nipples or genitals;

- purple subcutaneous nodules;

- histologically mainly mixed B and T lymphocytic infiltrates [11].

If the clinical manifestations of the disease cause suspicion of neuroborreliosis, immunological (serological) tests should be performed to diagnose: blood serum and cerebrospinal fluid taking for analysis $[8$, 20]. In each case of neuroborreliosis in the cerebrospinal fluid there are inflammatory changes (pleocytosis, impairment of the blood-brain barrier, intrathecal synthesis of immunoglobulins). Normal cerebrospinal fluid is observed only in the very early stages of the disease or in patients with distal symmetrical polyneuropathy in association with chronic atrophic acrodermatitis. Borrelia-specific IgM antibodies are detected in the blood from the third week after the bite, and IgG antibodies - from the sixth. In late neuroborreliosis, high concentrations of $\mathrm{IgG}$ antibodies to Borrelia are always present if the patient is immunocompetent. IgG and IgM antibodies can persist for several years, despite the clinically curable infection. Therefore, positive serological results do not establish the presence of infection. If the diagnosis remains unclear, for example in patients with immunosuppression, the suspected infection can be confirmed by detecting the pathogen in the cerebrospinal fluid. However, the sensitivity of detection of the pathogen in the cerebrospinal fluid - culturally or by polymerase chain reaction in early neuroborreliosis is only $10-30 \%[16,20]$. 
Therapeutic tactics of various forms of LD still remain an urgent, partially solved problem. Mostly an assessment of the effectiveness of treatment is limited to monitoring the disappearance of erythema without further observation of the patient. The disappearance of clinical signs of LD is the main criterion for the success of treatment, as antibodies to $\mathrm{Bb}$ can persist for years. But, in our opinion, the possibility of long-term asymptomatic persistence of $\mathrm{Bb}$ necessitates a long-term control of the serological profile of specific antibodies after completion of therapy $[2,13]$.

The modern schemes of antibacterial therapy of neuroborreliosis used in the world and Ukraine are given, in particular:

Early neuroborreliosis

Facial nerve palsy: doxycycline $100 \mathrm{mg} * 2$ times a day.

Other manifestations: ceftriaxone $1.0 \mathrm{~g} * 2$ times a day, intravenously, 14-28 days.

\section{Late neuroborreliosis}

The drug of choice is ceftriaxone $1.0 \mathrm{~g} * 2$ times a day, intravenously, for 28 days [2].

According to the order of the Ministry of Health No. 133 of 19.07 .95$, LD is classified as a particularly dangerous infectious disease.

In Europe, the United States, LD is on the "list" of major diseases with which neurologists make a differential diagnosis, as it often mimics the clinic of neurological pathologies such as multiple sclerosis, Alzheimer's disease, systemic scleroderma, Lymeinduced arthritis. chronic fatigue syndrome, fibromyalgia, etc. There is no such practice in Ukraine yet, but the practical experience of our department (increasing the number of diagnosed cases of different periods of neuroborreliosis) proves that neurologists should be aware of the possibility of this disease in a particular patient and include LD in the differential series.

The article describes a clinical case of facial nerve palsy in women aged 57 years as a manifestation of early neuroborreliosis, diagnosis and treatment.

Patient N., 57 years old, applied to the neurological department of Ivano-Frankivsk Regional Clinical Hospital on October 30, 2018 with complaints of asymmetry of the face on the right, inability to close the right eye, food compaction behind the right cheek, fever $-37.4^{\circ} \mathrm{C}$ for two days, general weakness. From the anamnesis of the disease it is known that these complaints appeared on October 29, 18, in the morning. From 18.10.18 - there was redness in the right shoulder, which migrated over the body. Pains in the chest on the right along the intercostal spaces intensified at night were noted, a periodic increase in temperature to $38 .{ }^{\circ} \mathrm{C}$. Life history: material and living conditions are satisfactory, city resident, married, two children, active.

Objectively: Systemically: blood pressure 130/80 mm Hg., heart rate $-63 / \mathrm{min}$., respiratory rate - 16/min., vesicular auscultation respiration, body temperature $-37.2^{\circ} \mathrm{C}$. Heart tones are rhythmic, muffled. The abdomen is soft, not painful. Pasternatsky's symptom (-) on both sides. Neurological status: Eye fissures $\mathrm{D}>\mathrm{S}$, lagophthalmos, lacrimation on the right, pupils $\mathrm{D}=\mathrm{S}$, pupillary reactions are preserved, the reaction to light is preserved, the movement of the eyeballs is apparently preserved. Bell's symptom on the right. Can not frown forehead on the right, right cheek is puffed out, sunkened angle of the mouth on the right. The tongue is in midline. Tendon and periosteal reflexes of arms and legs $\mathrm{D}=\mathrm{S}$ are preserved. In the Romberg stance is stable, finger-to-nose test performs satisfactorily. Pathological foot signs, sensitivity disorders, meningeal symptoms absent.

\section{Examination:}

Magnetic resonance imaging (MRI of the cervical spine (October 25, 2018). Conclusion: Osteochondrosis. Herniated discs C3-C4, C4-C5, C5-C6, C6-C7. Th1-Th2-Th3-Th4 discs protrusion. Central degenerative stenosis of the spinal canal at the level of C5-C6 Space-occupying foramen of the spinous process and arches of Th1 (most likely - osteoma).

Contrast-enhanced MRI of the brain (30.10.2018). Conclusion: MR signs of dyscirculatory encephalopathy, mild degree. No data were found in favor of ACD or space-occupying brain formations.

Electrocardiogram (October 30, 2018): heart rate - 100-93 beats/min., Sinus tachycardia. Signs of moderate diffuse changes in the myocardium, reduced bioelectrical activity of the myocardium, dysmetabolic changes in the myocardium. CAD. AV conductivity is somewhat slowed down.

Chest radiograph (November 1, 2018) - lungs and heart within normal limits.

Ultrasound of the abdominal cavity (November 1, 2018) Gallbladder: elongated shape, after eating. Kidneys: normal size, right - not blocked, Bertini column $-2.7 \mathrm{~cm}$, cyst parenchyma 0.8$1.5 \mathrm{~cm}$, left - normal size, not blocked, Bertini column $-2.5 \mathrm{~cm}$, choledochus - and intrahepatic bile ducts - norm, portal vein $-1.14 \mathrm{~cm}$. Liver: with signs of hepatosis. Pancreas: not thickened, hyperechoic. Spleen: normal finding. Flatulance. No free fluid in the abdominal cavity.

Echocardiography of the heart (November 5, 2018). Conclusion: diastolic LV dysfunction type I. 
Concentric LV hypertrophy. No valvular pathology. Cavities of the heart are not dilated Systolic function is preserved. $\mathrm{FVC}-54 \%$.

Vertebrologist (November 1, 2018). Diagnosis: Osteoma of the C7 vertebral arch with pain. Degenerative stenosis of C-spine at the level of C4-C7.

Laboratory tests:

General blood test (October 30, 2018): hemoglobin $-129 \mathrm{~g} / \mathrm{l}$, erythrocytes $-4.22 \times 10^{12} / 1$, platelets - 289 thousand cells/1 $\mathrm{ml}$ of blood, leukocytes $17.61 \times 10^{9} / 1$, ESR $-30 \mathrm{~mm} / \mathrm{h}$, stab cells $-6 \%$, segmented $-75 \%$, eosinophils - $1 \%$, lymphocytes $13 \%$, monocytes $-5 \%$.

RW (October 31, 2018) - negative. Blood sugar $-5.4 \mathrm{mmol} /$ liter.

Biochemical analysis of blood (October 30, 2018): albumin $-45.4 \mathrm{~g} / \mathrm{l}$, total cholesterol $-4.13 \mathrm{mmol} / \mathrm{l}$, urea $-6.5 \mathrm{mmol} / \mathrm{l}$, creatinine $-74 \mu \mathrm{mol} / \mathrm{l}, \mathrm{AST}-18.3$ Units/l, ALT - 21.1 Units/1, TG - $1.05 \mathrm{~g} / 1$.

As the appearance of facial palsy in the patient was preceded by pain in the chest along the right intercostal spaces, fever, herpes lesion of the peripheral nervous system - Herpes Zoster was suspected, in which thoracic dermatomes $(50-55 \%)$ are affected the most common of the spinal ganglia, as well as lesion of the geniculate ganglion (Ramsey-Hunt syndrome).

Varicella Zoster virus was determined in the blood (October 31, 2018 - taken, November 4, 2018 - received): Varicella Zoster, IgG, IgM: - negative result. Before receiving the results - the patient was prescribed acyclovir.

Treatment was started from the first day of admission to the neurological department with the following drugs: dexamethasone, trental, dialiponturbo, furosemide, ketonal, calcium, elfunate, acyclovir (from the second day, after taking tests). Against the background of treatment, the patient's condition gradually improved - the asymmetry of the face decreased, the right eye began to close, and the temperature normalized. From the fourth day a rounded swelling of bluish-red color appeared on the right earlobe, constantly painful, as well as swelling of the interphalangeal joints of both hands, a repeated elevation of temperature $-37.2-37.5^{\circ} \mathrm{C}$. Ultrasound of the right and left upper extremities was performed (November 6, 2018). No effusion in the synovial bursa of the I finger of the right radiocarpal joint. Palmar surface of the hands infiltration, edema at a depth of $1.1 * 0.6 \mathrm{~cm}$.

Given the swelling of the joints, an increase in ESR $-30 \mathrm{~mm} / \mathrm{h}$ and a decrease in the number of lymphocytes $-13 \%$, the patient was prescribed a blood test to rule out rheumatoid arthritis (09.11. 2018,): Fc fragment IgG autoantibodies IgA-0.12,
Fc- fragment IgG autoantibodies IgG-0.06, Fc fragment IgG autoantibody IgM-3.29 ( $\uparrow$ ). Cyclic citrulline peptide (A-SSR), IgG- $<7$ antibodies. The results obtained - the norm.

Suspected LD. The patient categorically denied the tick bite, as she had not visited the forest or picnicked for 4 months, although she recalled that in August she had a rest in Truskavets and walked in the forest-park area. Agreed to undergo a blood test by Western-blot. Immunological blood test (November 8, 2018): Borrelia burgdorferi, IgM antibodies: p41, p39, OspC Ba (Borrelia afzelii), OspC $\mathrm{Bb}$ (Borrelia burgdorferi), OspC $\mathrm{Bb}$ (Borrelia garinii), IgM - detected. Borrelia burgdorferi, IgG antibodies: VisE (Borrelia afzelii), VisE (Borrelia burgdorferi), VisE (Borrelia garinii), p41, p39, OspC (B. afzelii), IgG - detected.

The patient refused from lumbar puncture. Advised by an infectious disease specialist (November 12, 2018). Diagnosis: Lyme disease. Ceftriaxone $2 \mathrm{~g}$ per day was administered intravenously for 21 days. During the next 3 days, the patient's body temperature returned to normal, the swelling, redness and pain of the right earlobe and interphalangeal joints of both hands disappeared, the face was symmetrical, complete closing of the right eye.

Thus, a clinical diagnosis was made: Lyme disease, early infection, disseminated stage: neuroborreliosis, moderate palsy of the right facial nerve.

The patient with improved condition was discharged for further treatment under the supervision of an infectious disease doctor of the Regional Clinical Infectious Diseases Hospital. Recommended: observation of an infectious disease doctor for 2 years. Clinical and laboratory examinations (including Western-blot blood tests) 1, 3, 6, 12,24 and 48 weeks after completion of antibacterial therapy.

\section{RESULTS AND DISCUSSION}

The three subtypes of neuroborreliosis (European, Siberian, and Far Eastern) that cause the disease lead to similar but not identical diseases. More than half of patients with neuroborreliosis caused by the European subtype have a characteristic two-phase course of the disease. The initial phase, which corresponds to viremia and lasts for 18 days is characterized by fever, headache and malaise. Then there is an improvement or even an asymptomatic interval lasting about 1 week, and then the symptoms of neurological damage appear. The second phase is represented by meningitis, meningoencephalitis or meningoencephalomyelitis in $50 \%, 40 \%$ and $5-10 \%$ of adult patients, respectively. The severity of the disease increases with age: 
meningitis predominates in children, while meningoencephalitis predominates in the elderly $[12,15]$.

The presented clinical case of facial nerve neuropathy in women demonstrates the complexity of the diagnosis of LD. During hospitalization, the clinic of facial palsy dominated in the patient. The patient's denial of contact with the tick in this case caused a delay in LD diagnosis making. Auxiliary criteria for correct diagnosis were: the presence of radicular pain in the chest (mostly at night), fever, the presence of migrating erythema (in the hospital it was not observed), the appearance of lymphocytoma and damage to the joints of the hands (rarely, in mainly large and medium joints are involved). More than half of the patients (59.7\%) develop ME during the course of the disease. ME is associated with the etiological agent of LD - Borrelia garinii, and is characterized by a faster spread than in other species of Borrelia [10,18].

During the stay in the hospital the patient's condition changed wave-like. After the initial appointment of dexamethasone - a short-term improvement. However, later there was a rise in body temperature again, and benign lymphocytoma appeared. Immunological study with the detection of high titers of $\operatorname{IgM}$ and $\operatorname{IgG}$ antibodies to Borrelia afzelii, Borrelia burgdor $\neg$ feri, Borrelia garinii was crucial for the correct diagnosis - LD. Prescribed anti-bacterial therapy (ceftriaxone) led to the disappearance of symptoms.

We suspected Bannwart's syndrome (BS) in this patient, but no study of cerebrospinal fluid was performed - there is no confirmation of the presence of serous meningitis, so it does not allow to consider it reliably verified in this clinical case.

BS is a rare manifestation of early neuroborreliosis (disseminated stage of early infection) and is more often described in patients with LD in Europe compared to the United States [10]. BS is cha- racterized by radicular pain (cervical and thoracic radiculitis), cranial or peripheral neuropathy (especially facial and excretory nerve), meningitis with lymphocytic pleocytosis $[5,14]$. BS is usually manifested by severe, herpes zoster-like, segmental pain that is more bothersome at night, responds poorly to conventional painkillers, being burning, stabbing, or bursting. $75 \%$ of patients develop neurological deficit 1-4 weeks after, usually in the form of flaccid paralysis or segmental sensory disturbances. Cranial nerve neuropathy occurs in approximately $60 \%$ of patients with BS. In more than $80 \%$ of such cases, involvement of the facial nerve leads to the typical peripheral facial palsy (in a third of cases - bilateral). Any other cranial nerve can also be affected, but no cases of olfactory nerve involvement have been reported [7, 19].

\section{CONCLUSIONS}

The diagnosis of neuroborreliosis is important because patients with facial palsy should receive antibiotic therapy not to accelerate the treatment of facial nerve neuropathy, which usually heals within a few weeks, whether or not antimicrobial therapy is given, but rather to prevent complications $[6,15]$.

1. ME and benign lymphocytoma are important clinical manifestations of neuroborreliosis, in particular early stage, which can help in the correct diagnosis and treatment.

2. Neuroborreliosis must be confirmed by specific laboratory methods (blood serum and cerebrospinal fluid) - enzyme-linked immunosorbent assay, Westernblot (determination of specific antibodies separately to individual Borrelia antigens).

3. Mandatory monitoring of the patient with neuroborreliosis and serological control.

Conflict of interest. The author declares no conflict of interest.

\section{REFERENCES}

1. Kosovska TM, Kosovska VO. [Case of Lyme borreliosis in a child]. Aktual'na infektolohiya. 2019;1:4245. Ukrainian.

doi: https://doi.org/10.22141/2312-413x.7.1.2019.159226

2. Popovych OO. [Lyme borreliosis: a modern problem of infectology (clinical lecture)]. Aktual'na infektolohiya. 2016;3:114-122. Ukrainian.

doi: https://doi.org/10.22141/2312-413x.3.12.2016.81725

3. Fedonyuk LYa, Chaban HP, Rybits'ka LN, Avsyukevych OS. [Epidemiological characteristic, clinical and diagnostic peculiarities of the systemic tick-borne Lyme in Ternopil region]. Tavrycheskyy medyko-byolohycheskyy vestnyk. 2013;1 (61):198-202. Ukrainian.
4. Shkilna MI. [Lyme-borreliosis in forestry workers of Ternopil region]. Infektsiyni khvoroby. 2016;1:36-40. Ukrainian.

5. Shah A, O’Horo JC, Wilson JW, Granger D, Elitza ST. An Unusual Cluster of Neuroinvasive Lyme Disease Cases Presenting With Bannwarth Syndrome in the Midwest United States. Open Forum Infectious Diseases. 2018;4:1-3.

doi: https://doi.org/10.1093/ofid/ofx276

6. Wittwer B, Pelletier S, Ducrocq X, et al. Cerebrovascular events in lyme neuroborreliosis. J Stroke Cerebrovasc Dis. 2015;24:1671-78.

doi: https://doi.org/10.1016/j.jstrokecerebrovasdis.2015.03.056 
7. Rauer S, Kastenbauer S, Fingerle V, Hunfeld KP, Huppertz HI, Dersch R. Clinical practice guideline: Lyme neuroborreliosis. Deutsches Ärzteblatt International. 2018;115:751-6.

doi: https://doi.org/10.3238/arztebl.2018.0751

8. Moutailler S, Valiente Moro C, Vaumourin E, Michelet L, Tran FH, Devillers E, et al. Co-infection of ticks: the rule rather than the exception. PLoS Negl Trop Dis. 2016;10(3):1-17.

doi: https://doi.org/10.1371/journal.pntd.0004539

9. Cooper L, Branagan-Harris M, Tuson R, Nduka C. Lyme disease and Bell's palsy: an epidemiological study of diagnosis and risk in England. British Journal of General Practice. 2017;5:329-35.

doi: https://doi.org/10.3399/bjgp17X690497

10. Ogrinc K, Lusa L, Lotric-Furlan S, Bogovic P, Stupica D, et al. Course and Outcome of Early European Lyme Neuroborreliosis (Bannwarth Syndrome): Clinical and Laboratory Findings. Clinical Infectious Diseases. 2016;63(3):346-53. doi: https://doi.org/10.1093/cid/ciw299

11. Hofmann H, Fingerle V, Hunfeld K-P, Huppertz H-I, Krause A, Rauer S, et al. Cutaneous Lyme borreliosis: guideline of the German Dermatology Society. GMS Ger Med Sci. 2017;15:1-31. doi: 10.3205/000255

12. Hofhuis A, Bennema S, Harms M, van Vliet AJ, Takken W, van den Wijngaard CC, et al. Decrease in tick bite consultations and stabilization of early Lyme borreliosis in the Netherlands in 2014 after 15 years of continuous increase. BMC Public Health. 2016;16(425):1-6.

doi: https://doi.org/10.1186/s12889-016-3105-y

13. Halperin JJ. Nervous system Lyme disease. Infect Dis Clin North Am. 2015;29:241-53. doi: https://doi.org/10.1016/j.idc.2015.02.002
14. Koedel U, Fingerle V, Pfister HW. Lyme neuroborreliosis-epidemiology, diagnosis and management. Nat Rev Neurol. 2015;11:446-56.

doi: https://doi.org/10.1038/nrneurol.2015.121

15. Lotric-Furlan S, Strle F. Peripheral facial palsy in tick-borne encephalitis. Clinical Microbiology and Infection. 2011;18 (10):1027-32.

doi: https://doi.org/10.1111/j.1469-0691.2011.03719.x

16. Fingerle V, Eiffert H, Gessner A, et al.: Lyme borreliose. In: Podbielski A., Abele-Horn M., Hermann M., Kniehl E., Mauch H., Rüssmann H. (eds.): MiQ - Qualitätsstandars in der mikrobiologisch-infektiologischen Untersuchung. 2nd edition. München, Jena: Elsevier, Urban \& Fischer 2017.

17. Ogrinc K, Wormser GP, Visintainer P, Maraspin V, Lotric-Furlan S, Cimperman J, et al. Pathogenetic implications of the age at time of diagnosis and skin location for acrodermatitis chronica atrophicans. Ticks Tick Borne Dis. 2017;8(2):266-9.

doi: https://doi.org/10.1016/j.ttbdis.2016.11.011

18. Ogrinc K, Lotric-Furlan S, Maraspin V, et al. Suspected early Lyme neuroborreliosis in patients with erythema migrans. Clin Infect Dis. 2013;57:501-509. doi: https://doi.org/10.1093/cid/cit317

19. Dessau RB, et al. To test or not to test? Laboratory support for the diagnosis of Lyme borreliosis: a position paper of ESGBOR, the ESCMID study group for Lyme borreliosis. Clinical Microbiology and Infection. 2018;24:118-124.

doi: https://doi.org/10.1016/j.cmi.2017.08.025

20. Zajkowska J, Garkowski A, Moniuszko A, et al. Vasculitis and stroke due to lyme neuroborreliosis - a review. Infect Dis (Lond). 2015;47:1-6. doi: https://doi.org/10.3109/00365548.2014.961544

\section{СПИСОК ЛІТЕРАТУРИ}

1. Косовська Т. М., Косовська В. О. Випадок Лаймбореліозу в дитини. Актуальна інфектологія. 2019. № 1. C. $42-45$.

DOI: https://doi.org/10.22141/2312-413x.7.1.2019.159226

2. Попович О.О. Лайм-бореліоз: сучасна проблема інфектології: клінічна лекція. Актуальна інфектологія. 2016. № 3. С. 114-122. DOI: https://doi.org/10.22141/2312-413х.3.12.2016.81725

3. Федонюк Л. Я., Ч Чабан Г.П., Рибіцька Л. Н., Авсюкевич О. С. Епідемологічна характеристика, особливості клінічного перебігу та діагностики системного кліщового бореліозу в Тернопільській області. Тавр. медико-биологический вест. 2013. Т. 61, № 1. C. 198-202.

4. Шкільна М. I. Лайм-бореліоз у працівників лісових господарств Тернопільської області. Інфек. хвороби. 2016. № 1. С. 36-40.

5. An Unusual Cluster of Neuroinvasive Lyme Disease Cases Presenting With Bannwarth Syndrome in the Midwest United States / A. Shah et al. Open Forum Infectious Diseases. 2018. Vol.4. P. 1-3. DOI: https://doi.org/10.1093/ofid/ofx276
6. Cerebrovascular events in lyme neuroborreliosis / B. Wittwer et al. J. Stroke Cerebrovasc Dis. 2015. Vol. 24. P. 1671-1678.

DOI: https://doi.org/10.1016/j.jstrokecerebrovasdis.2015. 03.056

7. Clinical practice guideline: Lyme neuroborreliosis. / S. Rauer et al. Deutsches Ärzteblatt Inter. 2018. Vol. 115. P. 751-756.

DOI: https://doi.org/10.3238/arztebl.2018.0751

8. Co-infection of ticks: the rule rather than the exception / S. Moutailler et al. PLoS Negl Trop Dis. 2016. Vol. 10, No. 3. P. 1-17.

DOI: https://doi.org/10.1371/journal.pntd.0004539

9. Cooper L., Branagan-Harris M., Tuson R. and Nduka C. Lyme disease and Bell's palsy: an epidemiological study of diagnosis and risk in England. $B r . J$. of General Practice. 2017. Vol. 5. P. 329-335. DOI: https://doi.org/10.3399/bjgp17X690497

10. Course and Outcome of Early European Lyme Neuroborreliosis (Bannwarth Syndrome): Clinical and Laboratory Findings / K. Ogrinc et al. Clinical 
Infectious Diseases. 2016. Vol. 63, No. 3. P. 346-353. DOI: https://doi.org/10.1093/cid/ciw299

11. Cutaneous Lyme borreliosis: guideline of the German Dermatology Society / H. Hofmann et al. GMS Ger Med Sci. 2017. Vol. 15. P. 1-31.

12. Decrease in tick bite consultations and stabilization of early Lyme borreliosis in the Netherlands in 2014 after 15 years of continuous increase / A. Hofhuis et al. BMC Public Health. 2016. Vol. 16, No. 425. P. 1-6. DOI: https://doi.org/10.1186/s12889-016-3105-y

13. Halperin J. J. Nervous system Lyme disease. Infect Dis Clin North Am. 2015. Vol. 29. P. 241-253. DOI: https://doi.org/10.1016/j.idc.2015.02.002

14. Koedel U., Fingerle V., Pfister H. W. Lyme neuroborreliosis-epidemiology, diagnosis and management. Nat Rev Neurol. 2015. Vol. 11. P. 446-456. DOI: https://doi.org/10.1038/nrneurol.2015.121

15. Lotric-Furlan S., \& Strle F. Peripheral facial palsy in tick-borne encephalitis. Clin. Microbiology and Infection. 2011. Vol. 18, No. 10. P. 1027-1032. DOI: https://doi.org/10.1111/j.1469-0691.2011.03719.x

16. Lyme borreliose. In: Podbielski A., AbeleHorn M., Hermann M., Kniehl E., Mauch H., Rüs- smann H. (eds.): MiQ - Qualitätsstandars in der mikrobiologisch-infektiologischen Untersuchung / V. Fingerle et al. 2nd ed. München, Jena: Elsevier, Urban \& Fischer 2017.

17. Pathogenetic implications of the age at time of diagnosis and skin location for acrodermatitis chronica atrophicans / K. Ogrinc et al. Ticks Tick Borne Dis. 2017. Vol. 8, No. 2. P. 266-269.

DOI: https://doi.org/10.1016/j.ttbdis.2016.11.011

18. Suspected early Lyme neuroborreliosis in patients with erythema migrans / K. Ogrinc et al. Clin Infect Dis. 2013. Vol. 57. P. 501-509.

DOI: https://doi.org/10.1093/cid/cit317

19. To test or not to test? Laboratory support for the diagnosis of Lyme borreliosis: a position paper of ESGBOR, the ESCMID study group for Lyme borreliosis / R. B. Dessau et al. Clinical Microbiology and Infection. 2018. Vol. 24. P. 118-124.

DOI: https://doi.org/10.1016/j.cmi.2017.08.025

20. Vasculitis and stroke due to lyme neuroborreliosis - a review / J. Zajkowska et al. Infect Dis (Lond). 2015. Vol. 47. P. 1-6.

DOI: https://doi.org/10.3109/00365548.2014.961544 